"P2P lending as an alternative to bank lending in Ukraine"

\begin{tabular}{|c|c|c|}
\hline AUTHORS & Alexander Lavryk & \\
\hline ARTICLE INFO & $\begin{array}{l}\text { Alexander Lavryk (2016). P2P Ie } \\
\text { Ukraine. Banks and Bank Syste } \\
\text { doi:10.21511/bbs.11(4).2016.02 }\end{array}$ & lative to bank lending in \\
\hline DOI & http://dx.doi.org/10.21511/bbs.1 & \\
\hline RELEASED ON & Friday, 09 December 2016 & \\
\hline JOURNAL & "Banks and Bank Systems" & \\
\hline FOUNDER & LLC “Consulting Publishing Cor & "erspectives" \\
\hline & & $\begin{array}{l}=-0 \\
=0\end{array}$ \\
\hline NUMBER OF REFERENCES & NUMBER OF FIGURES & NUMBER OF TABLES \\
\hline 0 & 0 & 0 \\
\hline
\end{tabular}

(C) The author(s) 2023. This publication is an open access article. 


\title{
P2P lending as an alternative to bank lending in Ukraine
}

\begin{abstract}
The goal of the article is to consider peer-to-peer lending and its interaction with bank lending that creates an aggregate hybrid lending. The article's objective is the research of development of P2P lending on the financial market and beyond, which is particularly relevant today. This goal is achieved by using the methods of evaluation and comparative analysis of different principles, which makes it possible to structure the general scientific understanding of P2P lending with the help of statistical methods. The study of the dynamics and structure of peer-to-peer lending in various countries for the period 2005-2016 led to the conclusion that in Ukraine, there is a decline in the share of bank lending in favor of peer-to-peer lending in the total amount of loans with an increasing role of non-bank and hybrid forms of lending in ensuring economic growth.
\end{abstract}

Keywords: peer-to-peer lending, banking institutions, credit portfolios of banks, investments, financial intermediaries, financial intermediation.

JEL Classification: A1, G21, G24.

\section{Introduction}

The decline in popularity of financial and credit institutions among the population, their inability to meet credit demand of real enterprises under the conditions of inadequacy of investment resources within the national economy creates conditions for the emergence of new types of financial services (The Economist, 2013), which are capable of intensifying the participation of economic entities in the formation of investment flows. The contemporary alternative type of financial intermediation is peer-to-peer lending, which is fairly widespread internationally, but which remains a new phenomenon on the domestic financial market making it necessary to study both the theoretical provisions in the functioning of the system of peer-to-peer lending and the improvement of practical peculiarities of its implementation.

A new form of private lending is $\mathrm{P} 2 \mathrm{P}$ projects. The idea of private $\mathrm{P} 2 \mathrm{P}$ lending came from the US and now is very popular in the Western countries - this service is now competing with banking lending on equal terms.

\section{Analysis of the recent research and publications}

Given the relatively short period of existence of P2P lending, the domestic scientific literature is characterized by a fragmented approach to the study of its main principles as a new way of providing investment flows to the country's economy.

The theoretical and methodological foundation for the development of peer-to-peer lending and bank lending is embodied in the works of foreign scholars, such as: A. Agrawal $(2011,2013)$, G.K.C. Ahlers (2012), P. Belleflamme (2014), E. Burkett

(C) Alexander Lavryk, 2016

Alexander Lavryk, Candidate of Economic Sciences, Assistant professor of the Department of Finance and Credit, VN Karazin Kharkiv National University, Ukraine.
(2011), N. Chen (2011), B. Hallen (2012), J. Hemer (2011), H. Jenkins, V. Kuppuswamy, J. Lerner (1995), J. Light, M. Lin (2013), A. Ley (2011), E. Mollick (2014), J. Morduch (1999), M. Poetz (2012), A. Schwienbacher (2010), etc. The specifics of peer-to-peer lending and its prospects in terms of stimulation of investment potential of the economy is partially covered in the works of such scholars as V. Artamonov (2012), I. Vasylchuk (2013), A. Vlasov (2012), B. Gates (2007), O. Dluhopolsky (2011, 2012), A. Dolhyn (2013), S. Leonov and Y. Petrushenko (2014), but, to date, the domestic scientific literature is characterized by the absence of fundamental research that comprehensively describes the features of peer-to-peer lending. Given the necessity of developing new instruments to increase the volumes of internal investments in the national economy, especially from the perspectives of developing small and medium businesses, the research of the problems of P2P lending is of particular relevance and practical significance.

\section{Formation of the paper's goals}

The purpose of the article is the development of scientific and methodological principles and organizational mechanisms of implementing new forms of peer-to-peer lending, which caused the development of modern mechanisms that are alternative to bank lending, as well as the creation of hybrid forms of financial intermediation with the combination of peer-to-peer and bank lending.

The article's objective is the research of development of P2P lending on the financial market and beyond, which is particularly relevant today. This goal is achieved by using the comparative analysis of different principles, which makes it possible to structure the general scientific understanding of P2P lending with the help of statistical methods.

The subject of the article is peer-to-peer lending and its forms of interaction with bank lending that create an aggregate hybrid lending. 


\section{Presentation of the main material}

Preconditions for the emergence of peer-to-peer lending were a revolution in the system of investment borders and globalization of society through the use of digital instruments that made it possible to conclude and implement loan agreements in noncontact form via online services and led to the growing convenience and efficiency of investment processes (Dluhopolskyy, A., 2011; Lin, M., 2013).

Peer-to-peer lending is a type of lending, which is realized directly between unrelated parties without the financial intermediary by using online platforms for establishing contacts between the participants of credit relations and assessing the solvency of borrowers. In the scientific literature, this method of credit relations is called social lending, peer-to-peer lending or P2P lending (Petrushenko, 2014).

The current stage of development of the peer-to-peer lending market is characterized by its rapid growth, which manifests itself as an increase in the volumes and number of transactions, expansion of the range of services that can be made by using online platforms. Given the fact that financial intermediaries are not involved in the process of $\mathrm{P} 2 \mathrm{P}$ lending, its rapid development creates serious threats to banking activity, as transactions between individuals occur only through the use of Internet services, which provide lower commission fees than the cost of banking services. In comparison with the traditional services of financial intermediation, the advantages of peer-to-peer lending make it possible, on the one hand, to raise the level of return on the invested capital for physical persons who act as individual creditors and, on the other hand, to lower the cost of the obtained loans for the users of financial resources in view of the fact that the average commission on online platforms is $1-2 \%$, while the level of interest margin of banking institutions in modern conditions of the financial market's functioning reaches 10-15\% (Petrushenko, 2014).

At the same time, in spite of the obvious advantages of P2P loans related to price characteristics, so far, this type of lending has not received a significant level of user confidence, which is due, above all, to the very low level of customer protection, the absence of state guarantees and intervention of regulatory authorities in the functioning of this kind of services. At the present stage, the responsibility for the fair implementation of agreements lies mostly with the participants themselves, as the role of Internet services in ensuring the security of deposits is limited only to the gathering of information about customers, which creates opportunities for financial fraud and machinations, given the absence of objec- tive legal restrictions regarding the realization of such agreements. However, despite the low level of financial security, the analysis of statistical data on the development of the market of P2P lending shows its dynamic development. In particular, according to the information provided by the British Peer-to-Peer Finance Association, as of the end of 2013, more than 86,000 creditors took part in the transactions of peer-to-peer lending, which provided funding for consumer loans to 70,000 borrowers, as well as about 4 thousand investment loans for business needs. Thus, the annual growth of the total market worldwide reached $121 \%$ (BP2PFA).

The dominant role in peer-to-peer lending agreements belongs to unsecured personal loans, in which borrowers are physical persons who do not use collateral to reduce the risk of the lender in case of the borrower's insolvency. Along with this, some P2P services make it possible for business entities to obtain loans.

There are two approaches to determining the cost of credit: the setting of interest rates directly by the owners of financial resources under the conditions of reverse auction (Chen, N., 2011), or by decision of the organizer on the basis of information about the loan terms and creditworthiness of the borrower. The cost of the loan, like in traditional bank lending, depends on the likelihood of its return, allowing lenders to manage risks, and creates opportunities to diversify investments by providing loans to borrowers with different levels of paying capacity. At the same time, P2P lending agreements are the most risky for the owners of financial resources, as the loss of their financial resources as a result of insolvency of the borrower and the bankruptcy of the company that mediates the process of peer-to-peer lending is not compensated by the state.

Organization of the process of peer-to-peer lending is provided by specialized $\mathrm{P} 2 \mathrm{P}$ platforms that carry out a commercial activity generating profits both through commission fees for credits collected from borrowers and by setting up a charge for servicing the owners of financial resources (Goff Sh.).

Extensive opportunities of using automated services allow credit intermediaries to significantly reduce costs for conducting their activities, which reduces the costs of servicing compared to traditional financial and credit companies and, in turn, creates opportunities to reduce the cost of credits for borrowers and to increase revenues for lenders (Dluhopolsky, A., 2012).

To participate in the conclusion of $\mathrm{P} 2 \mathrm{P}$ lending agreements, one must be registered and tested on the appropriate site as a lender or borrower, which would 
make it possible to use the possibilities of conducting financial transactions between the cards of participants of credit agreements in the on-line mode. According to the results of personal activity, a rating of borrowers is formed, the criteria of which include the completeness of the presented individual information, the level of business activity and credit history within the respective platform. This rating can be used by creditors for making decisions to invest resources and as an indicator of the borrower's reliability.

It should be noted that in order to increase the reliability of investment for lenders, P2P lending platforms attract collection agencies to work with problem loans using traditional mechanisms of working with debtors.

At the present stage of development of financial intermediation, peer-to-peer lending has not yet acquired a clear position in the classification of financial services and, sometimes, it is treated as an alternative to their traditional types. At the same time, $\mathrm{P} 2 \mathrm{P}$ lending has a number of specific features: commercial nature of loans; establishing of relations between the participants of the lending process directly during the conclusion of agreements; use of specialized credit intermediaries to establish connections between the owners and users of financial resources; P2P lending services are provided on-line; areas of investments of funds are determined directly by their owners; lack of state guarantees regarding repayment of the granted loans; the instruments of loan realization include securities eligible for sale on the secondary market.

Due to some differences compared with the classical banking activities, specialized credit intermediaries belong to the class of non-bank financial institutions. Thus, their activity does not require a banking license, while a number of the offered services are limited to standardized loans and investments. In spite of the transformational character inherent to $\mathrm{P} 2 \mathrm{P}$ lending, which manifests itself in the possibility of attracting a large number of investors to financing one loan, the owners of financial resources can determine the areas of placing their funds, which is not typical for banking. In addition, unlike banks, specialized credit intermediaries cannot raise funds from other than voluntary investment sources to support their business activity (The Economist, 2013).

Similarly to the retail banking business, customers of peer-to-peer lending companies are the subjects that require financial resources the relations with whom are not mediated by the interference of additional financial intermediaries.

On the initial stages of development of peer-topeer lending, the target audience of specialized financial intermediaries included customers from the regions with low levels of financial resources, which were also characterized by the absence of the need to create collateral for loans and low levels of income, making it possible to use competitive advantages in comparison with banking services by reducing the requirements to their levels of solvency. However, at the same time, the current conditions of functioning of $\mathrm{P} 2 \mathrm{P}$ lending are characterized by the opposite tendencies due to the increasing problems with loan repayments, and, therefore, the desire of investors to reduce risks investing their money (Agrawal, A., 2011).

In determining the place of peer-to-peer lending among a wide range of services of financial intermediaries, it is expedient to explore its differences from their main types. We should note that despite some similarities with the functioning of mutual credit institutions such as credit unions, cooperative banks, savings and loan associations, etc., organization of $\mathrm{P} 2 \mathrm{P}$ lending services provides for a clear distinction of the roles of lenders, borrowers and owners of companies, i.e., credit intermediaries. Accordingly, the range of stakeholders is not limited to the presence of common characteristics and regularity of their relationship. Moreover, despite the fact that the expenses on organization of activities of specialized credit intermediaries are covered by fees charged from both parties of the lending process, both investors and borrowers have no influence on the management of these institutions. In addition, the activity of P2P lending platforms is commercial in nature and aimed at increasing the profits from their operation (The Economist, 2013).

The commercial nature of this activity demonstrates the impossibility of identifying peer-to-peer lending with the functioning of crowdfunding platforms and joint financing companies that mediate investment flows on the conditions of non-profitability (Vasylchuk, 2013; Agrawal, A., 2013; Mollick, E., 2014; Schwienbacher, A., 2010).

Along with this, intermediaries of peer-to-peer lending differ significantly from microfinance institutions, because the amounts of loans are not limited. When the loans are given, credit history of the borrower is important and the loan may be given both to physical persons for consumption purposes and entrepreneurs.

Analyzing the role of peer-to-peer lending on the financial market, it should be noted that its functioning is characterized by significantly lower liquidity levels and market fluctuations compared to transactions with securities (Burkett, E., 2011).

The development of P2P lending in the world began in 2005. The first specialized credit intermediaries include the UK-based company Zopa, which today is one of the leaders of this market internationally. As of 
2015, the value of the American company Lending Club was estimated at more than $\$ 5$ billion US dollars. Experts estimate that an annual volume of peer-to-peer lending in the world exceeds 20 billion US dollars.

The essence of peer-to-peer lending is the provision of loans for different target groups, in which the formal role of lender does not belong to financial intermediaries, but is directly related to the owners of financial resources. The function of P2P lending platform as a credit intermediary ensures exclusively the establishment of relations between lenders and borrowers. However, despite the absence of financial guarantees to creditors from the platforms, the services they offer include credit scoring, technical support of financial transactions, as well as assistance in collecting arrears (Goff Sh.).

The function of banking in the investment process is only in the intermediation between the depositors of funds and their temporary users, but, at the same time, the role of banking institutions is to provide confidence to the participants of financial relations in maintaining their own well-being. The activity of peer-to-peer lending services is aimed at establishing trust relationships between the owners and borrowers of financial resources by using price advantages of such services. Today, the level of banking margin reaches $15 \%$ - annual deposit interest rates on the world market may be $1-2 \%$ and the minimum price of loans varies within $12-17 \%$, while the average cost of services of P2P platforms varies within $2-5 \%$ of the loan amount to the borrower and nearly $1 \%$ of the annual commission fee from the investor for organizing the process of lending.

The Internet is full of sites that actually represent an alternative to banks. These are credit exchanges and social networks, the participants of which can act either as borrowers or lenders. Borrowers receive loans on favorable terms, while lenders may invest their resources at high interest rates that are higher than bank interest rates (Agrawal, A., 2013). In most cases, such exchanges are created for students who need to pay their tuition. Currently, there are at least 12 such projects: 1983 GrameenBank; 2005 Zopa; 2005 Kiva; 2005 CircleLending - acquired by Virgin (now called Virgin Money); 2006 Prosper; 2007 Lending Club (owned by Facebook); 2007 GlobeFunder; 2008 Quizzle; 2008 Nexx; 2008 CommunityLend; 2008 GreenNote; 2009 iGrin.

Peer-to-peer lending enjoys the highest popularity in such financially developed countries as the United Kingdom and the USA. Thus, in 2015, the turnover of the British credit services Funding Circle, Zopa and RateSetter exceeded \$1 billion
US dollars, while annual volumes of American P2P platforms like Lending Club, Prosper and SoFi reach $\$ 4$ billion US dollars according to official figures.

As of 2014, the development of peer-to-peer lending projects became widespread around the world, making it possible to attract prominent businessmen to these processes as investors. In particular, joining the American Prosper platform was a top manager of Google, Eric Schmidt, who invests his own resources, while Yuri Milner, who owns the company Mail.ru Group, invested about 57 million US dollars by using the service Lending Club. Peer-to-peer lending is also developing in other countries such as Canada (Kiva and Sommunitylend.com services) and Germany (Smava.de platform). In the United States, there is even a startup that has combined such revolutionary trends in the economy as bitcoins and peer-to-peer lending: through BTCJam platform, it is possible to acquire a loan in cryptomoney. That is, by using peer-to-peer lending and bitcoins as crypto-money, it is possible to withdraw financial flows from the financial market and direct them anywhere. This is a modern, revolutionary and innovative development in the financial area.

The largest exchange of P2P loans Prosper was created in February 2006. Since then, it has raised 40 million dollars of venture investments. Each potential lender files an application in the amount of up to 25000 US dollars indicating a minimum interest rate, while borrowers (from the list of those approved by the lender) bargain by offering more favorable conditions (World Bank).

There are similar projects: Lending Club, Qifang, and the web-site Fynanz, which focuses exclusively on American students in Florida and New York (World Bank).

The development of such systems suggests that in the future, P2P networks and crowdsourcing can become a real alternative to banking institutions.

Of course, while the volumes of lending through $\mathrm{P} 2 \mathrm{P}$ projects remain insignificant compared to bank lending, the growth rate of this market is impressive. If this growth rate is maintained over the next $10-15$ years, bank loans may disappear as a market making factor.

Figure 1 shows the dynamics of $\mathrm{P} 2 \mathrm{P}$ lending in the UK in the period 2010-2015.

As can be seen from Figure 1, the dynamics of this form of lending as a non-banking form of financial intermediation is quite impressive. A similar dynamic of $\mathrm{P} 2 \mathrm{P}$ lending is observed in other countries such as the USA, France, Japan and China. 


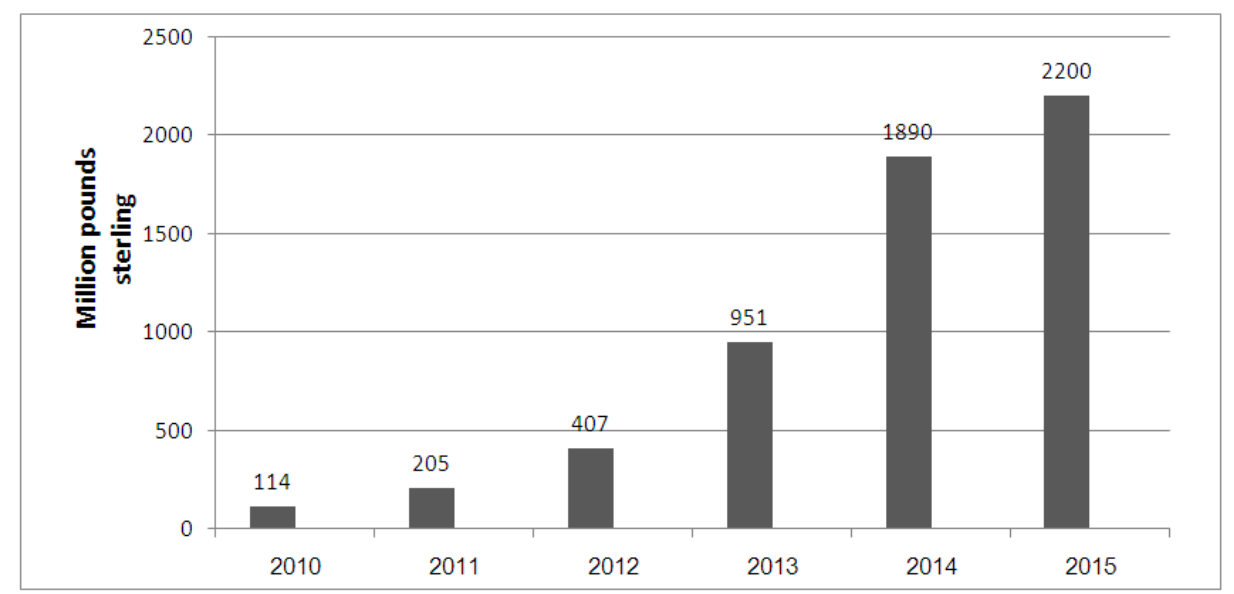

Fig. 1. Dynamics of P2P lending in the UK in the period 2010-2015 (World Bank)

In 2009, the American platform Zidisha launched a new phase in the development of peer-to-peer lending on the international level uniting lenders and borrowers from different countries without the participation of national financial intermediaries. It should be noted that this service makes it possible to determine the risk levels of borrowers without the use of quantitative indicators of their credit history.

The use of Zidisha service allows lenders and borrowers to make online deals with small amounts of loans. The activity of this company is aimed at establishing contacts between investors from more developed countries and borrowers from countries with low levels of the financial market's development, creating good prospects for their cooperation.

The processes of peer-to-peer lending are also developing on the domestic financial market. The most well-known platform is SimZirok service, which was realized in the form of a startup based on investments of Imperius Group. The activities of this service are associated with some specific features. In particular, interest rates for the loans are determined by way of auctions. There is also a limit for investing resources into one project per one investor, thus, reducing the risk to the market (SimZirok).

The functioning of the market of P2P lending in Ukraine is related to a number of different problems, non-stimulating role of which is noted by the management of SimZirok service. Thus, inadequate legal regulation of this sphere is manifested in the absence of common regulated mechanisms for the functioning of segregated accounts, provision of joint loans and involvement of collection agencies in recovering overdue debts and legal resolution of such cases. Development of peer-to-peer lending is also restrained by purely technical problems, including poor organization of the systems of electronic money and cashless payments. In addition, there are problems with information provision, which do not allow forming a clear and transparent database of customers that, consequently, reduces the level of investor confidence (SimZirok).

The next stage in the development of peer-to-peer lending on the Ukrainian financial market should improve information and financial literacy of potential customers of $\mathrm{P} 2 \mathrm{P}$ services enabling them to appreciate the advantages of this type of service and increase the level of trust. Considering the fact that intensification of the alternative types of financial services, including P2P lending, is not specified among the strategic objectives of the state policy of financial market development, the development of organizational, legal and financial mechanisms of its implementation remains to be the responsibility of self-regulating organizations of the financial market, as well as individuals who are interested in the development of this type of services (Vasylchuk, I., 2013).

It should be noted that despite the lack of guarantees of loan repayment on the part of P2P platforms, there are opportunities for collecting overdue debts by means of collection agencies, which often cooperate with credit intermediaries. Moreover, it is also possible to take particularly difficult cases to court.

Analyzing the specifics of peer-to-peer lending, it is appropriate to consider its key differences from traditional financial (banking) services in terms of major participants. Therefore, for investors, the process of peer-to-peer lending is manifested in the following aspects:

- higher level of income on invested capital compared to bank deposits;

- higher loan default risks, which are managed by independent selection of borrowers and possibilities of diversification of funds among different loans;

- monthly payment of invested resources and interest income;

- saving time on the process of investing through the use of online platforms. 
In turn, for borrowers, the process of peer-to-peer lending also has a number of specific characteristics:

- independent choice of the terms and the amount of loans, the ability to set the desired interest rates on loans;

- the probability of obtaining loans depends on the completeness of the provided information;

- the cost of the borrowed resources is formed by the interest rate paid to investors, as well as commission fees set by the P2P platform.

In spite of the fact that the development of $\mathrm{P} 2 \mathrm{P}$ lending originates from the funding of consumer loans, which are the main market for the largest platforms in this area, peer-to-peer lending is successfully used to finance various areas of economic activity. Today, in addition to consumer loans, the most common types of $\mathrm{P} 2 \mathrm{P}$ lending are the following:

- business loans - traditionally, their amounts are in the range of 50-500 thousand US dollars with maturities of several years. Gaining popularity on this market are the loans in the form of credit lines with the setting of the maximum loan amount, within which the company uses the funds paying interest according to the results of their use. The largest online platforms, which can be used to realize this type of loan, include Biz2Credit, Kabbage, Funding Circle;

- education loans - this type has become prevalent in the US, given the popularity of educational loans among the population. The use of peer-to-peer lending while obtaining an education is characterized by significant advantages compared with traditional state loans considering the individual nature of $\mathrm{P} 2 \mathrm{P}$ lending, which makes it possible to reduce interest rates for the students of the country's top universities. Providing this type of loans are such services as CommonBond, UpStart, SoFi;

- refinancing of receivables - this type of loans, which are given against requirements to counterparties, enables companies to increase their level of business activity not losing business relationships with partners that can occur with factoring agreements. This type of services can be implemented by using platforms BlueVine, MarketInvoice, FundBox;

- loans secured by commercial real estate - this type of loans is gaining popularity among businesses, because it makes it possible to temporarily raise funds during the early stages or expansion of business activity and to form additional working capital. Actively operating in this field are such companies as Patch of Land, Realty Mogul, Asset Avenue, Realty Shares, Lending Home;
- mortgage loans - today they are a promising area for the development of peer-to-peer lending, given the objective need in these long-term loans due to the emergence of additional risks.

In addition to the above-mentioned sub-types of peerto-peer lending, there are great prospects for its further development related, for example, to the opportunities to use guarantees to improve the reliability of borrowers and, therefore, to reduce the cost of borrowing.

Analyzing the trends in the development of the market of P2P lending, we should note the fact that today it can be described as a developing one, because despite the determined positions of leaders, there are opportunities for the emergence of new online platforms both in the new areas of peer-to-peer lending and in the existing ones. In addition, peer-to-peer lending is one of the most promising options for the expansion of activities of traditional financial intermediaries. For example, the world known company Goldman Sachs took a particular interest in this area.

At the present stage, the development of peer-topeer lending is characterized by major modifications of its participants with an increasing involvement of institutional investors as creditors, the participation of which creates opportunities for lending platforms to increase maximum amounts of loans accompanied by the emission of securities (Light, J.).

At the same time, despite the expansion of the structure of subjects, the activity of specialized credit intermediaries corresponds to the characteristics of the P2P lending process, the implementation of which takes place without the traditional financial and credit institutions.

The growing popularity of Internet services in ensuring investment flows attracts banking institutions to the formation of their own loan portfolios by using P2P platforms, which is especially important for small banks that are under significant competition and encounter problems attracting customers, as a result of which peer-to-peer lending gets new hybrid forms with participation of banks not as traditional financial intermediaries, but as investors of the previously accumulated capital.

Actualization of these trends opens new prospects for the development of peer-to-peer lending platforms that, on the one hand, eliminates its initial economic essence and, on the other hand, is an important step towards reducing the cost of bank resources for borrowers. At the same time, the main vector in the development of credit services is the attraction of private investors physical persons considering a higher level of their stability compared with institutional participants, who cannot divert their financial capital from their core activities (Light, J.). 
Consolidation of the position of peer-to-peer lending on the financial markets is demonstrated by continuous growth of $\mathrm{P} 2 \mathrm{P}$ credits in countries that are considered the world financial centers. Thus, in 2015 in the UK, the activity of P2P platforms was estimated at more than 2 billion pounds of granted loans according to the British Peer-toPeer Finance Association.

Indicators for the development of the UK market of peer-to-peer lending in 2015 are nearly two times bigger than the results achieved in the previous reporting period with a special emphasis on the results of the fourth quarter of 2015, which provided almost a third of the annual volume of new loans.

Along with the growth of financial indicators for this segment of financial services, there is a constant expansion in the number of entities involved in its functioning, which is especially true for individuals who attract financial resources through online platforms. In particular, on the UK market of P2P lending, the number of borrowers in 2015, compared to the figures of 2014 , increased by $96 \%$, while the number of investors increased by $22 \%$. There is a tendency of increasing volumes of funds invested by one person relatively to the amounts of loans, which are required by users - in 2015, 128 thousand creditors satisfied the needs of about 273 thousand borrowers (World Bank).

According to the estimates of the British Peer-toPeer Finance Association, the market of P2P lending is characterized by continuous growth and integration into other spheres of financial services, which is accompanied by increased customer trust and growing possibilities for peer-to-peer lending to compete with banking intermediation (BP2DFA).

Projections of the Centre of Economics and Business Research (CEBR) regarding the development potential of peer-to-peer lending predict the growth of lending volumes in 2020 up to 12.3 billion pounds, which is 10 times higher than the figure in 2014 (CEBR).

A successful functioning of this segment is also demonstrated by the list of major online platforms, which are represented mainly by the British and American companies that, on the one hand, increases the interest of other potential participants in this type of business and, on the other hand, raises the competitive barriers for entering this market.

On the Ukrainian financial market, the development of peer-to-peer lending services began in 2010, which was caused by the decrease in banking activity and the necessity to restore banks' operations by offering expensive products in the post-crisis period. At the same time, the activity of the first online plat- forms such as IVEXE Innovation Ventures, Credery.com, "Seven Stars" did not provide conditions for their long-term functioning and the one that remains is uCredit service, the financial performance indicators of which are closed to the public.

At the same time, the current phase of the post-crisis economic recovery is favorable for the emergence of new services of peer-to-peer lending considering the significant reduction in the number of banks and diminishing confidence to them among the population (Artamonov, V.).

An important advantage of peer-to-peer lending that can be used by economic actors is the conclusion of direct agreements between the lender and the borrower without the participation of banks, maximizing their economic benefits compared with the use of banking services. Despite the existing facts of cooperation between banks and credit platforms, banking activities remain a priority in financial intermediation, considering the high risks of peer-to-peer lending, the lack of regulatory provision and very low levels of awareness of this type of service among the population.

The basis for the functioning of credit services is commission income from attracting and providing financial resources, while the list of operational expenses is much narrower than that of other financial intermediaries, given the absence of need for the marketing campaigns, assessment of the creditworthiness of borrowers, diversion of funds for the formation of required reserves making it possible to increase the profitability of operations and, accordingly, to provide financial benefits for participants.

These features sharpen the competition between the peer lending and banking intermediation, which forms preconditions for their integration by means of participation of banks as investors on credit platforms. Such cooperation is mutually beneficial - on the one hand, banks simplify the procedure for promoting their credit products, on the other hand, credit platforms increase the volume of attracted investments.

Internationally, the most well-known cases of cooperation are characteristic of the leaders in the loan segment - the British companies Zopa (partner to Metro Bank) and Funding Circle (working with such banks as Santander and the Royal Bank of Scotland) and the US service Lending Club (with participation of Union Bank). The Ukrainian financial market offers an original version of integration of different types of financial services - the service of $\mathrm{P} 2 \mathrm{P}$ lending organized by the leader of the banking market PJSC "Privatbank".

The dynamics of the market of peer-to-peer lending is the most intensive in comparison with other areas of the credit system - the volumes of P2P 
credits in the world increased from the level of 1.2 billion dollars in 2012 to 64 billion dollars according to the results of 2016 (BP2PFA).

It is interesting that the major creditors are increasingly becoming banks themselves, which use this form of financial intermediation. According to the Economy Watch agency (World Bank), in the US, about $80 \%$ of big loans are provided by banks through the platforms of online lending. This mechanism has fundamental differences from online banking. In particular, more often than not, the borrower does not know exactly who gave him a loan, while lenders know exactly whom and for what purposes they provided with loans. This mechanism incorporates the best characteristics of consortium lending (association of creditors), online banking and social investment.

It should be noted that P2P lending has several disadvantages in comparison with bank lending and that they stand in the way of its further development. The comparative characteristics of P2P lending and bank lending is presented in Table 1.

Table 1. Characteristics of P2P lending and bank lending

\begin{tabular}{|c|c|c|}
\hline Criterion of comparison & Traditional bank lending & P2P lending \\
\hline $\begin{array}{l}\text { Accessibility of services } \\
\text { regardless of the place of } \\
\text { residence }\end{array}$ & $\begin{array}{l}\text { Available only in the region where the } \\
\text { borrower lives }\end{array}$ & $\begin{array}{l}\text { There are no restrictions regarding the region. Currently, only one country is restricted } \\
\text { due to the lack of legal regulation of this type of services on the international level }\end{array}$ \\
\hline $\begin{array}{l}\text { Package of documents for } \\
\text { receiving }\end{array}$ & $\begin{array}{l}\text { Depending on the goals and forms can be } \\
\text { big enough. The proof of income is obligato- } \\
\text { ry. }\end{array}$ & In most cases, it is only the validation of identity, minimum of documents \\
\hline Goals & $\begin{array}{l}\text { Clearly regulated, checked by the bank for } \\
\text { compliance }\end{array}$ & $\begin{array}{l}\text { At the request of the borrower, a clear formulation of goals increases the proba- } \\
\text { bility of receiving a loan. It is possible to obtain a loan for the implementation of } \\
\text { social initiatives at reduced rates }\end{array}$ \\
\hline Risk & $\begin{array}{l}\text { Pretty low due to the constant monitoring by } \\
\text { the bank of compliance with the lending } \\
\text { conditions }\end{array}$ & $\begin{array}{l}\text { High through the lack of control over the borrower. Written reports on the use of } \\
\text { credit resources may be in place (quite rare). In spite of this, the level of proble- } \\
\text { matic loans granted through the online platforms of P2P lending is less than } 2 \%\end{array}$ \\
\hline Cost & $\begin{array}{l}\text { Low in the countries of Europe and the } \\
\text { United States - (on average, 6-12\%) }\end{array}$ & $\begin{array}{l}\text { High, may reach } 20-22 \% \text {. However, in some cases, may be significantly reduced } \\
\text { if the lender is interested in getting other, non-financial effects from the loan, for } \\
\text { example, social ones }\end{array}$ \\
\hline Flexibility of conditions & $\begin{array}{l}\text { Regulated by banking programs. For } \\
\text { physical persons, it is almost impossible to } \\
\text { conclude an agreement on an individual } \\
\text { basis }\end{array}$ & $\begin{array}{l}\text { All terms are individual. There can be restrictions of the maximum amount } \\
\text { of loans and maturities }\end{array}$ \\
\hline
\end{tabular}

Banks should actively participate in this mechanism of lending in order not to lose their positions in the near future. This can be done by introducing new hybrid forms of financial intermediation - multi-participative bank lending. This form of financial intermediation is a combination of characteristics of the traditional bank lending, bank intermediation and a new form of financial relations that have been formed outside the formal financial market - P2P lending. In essence, remaining a part of $\mathrm{P} 2 \mathrm{P}$ lending, this service goes under the partial control of the bank, because the bank is the organizer and provider of such services.

The production of this service by the Ukrainian banks is expedient, because considering the low levels of overall confidence of economic agents to the financial sector, banks still remain the most popular and reliable financial intermediaries compared to insurance companies, mutual and corporate investment funds, credit unions, pawn shops, etc. In addition, based on the analysis of trends in the development of forms of financial intermediation, it can be argued that the Ukrainian society would negatively perceive a new form of financial intermediation, especially such a form that is not regulated by the current legislation, whereas its belonging to banks would create an atmosphere of confidence in its reliability. It should also be noted that banks in Ukraine are the most innovative financial intermediaries and have the best possibilities for the practical implementation of the necessary online resources and platforms.

Given the complexity of the use of this hybrid form of financial intermediation - multi-participative bank lending, different actors can participate in the process of its implementation. The most acceptable would be the scheme of multi-participative bank lending in Ukraine shown in Figure 2.

In this case, the bank, continuing to perform the traditional functions of financial intermediary, concentrates its efforts mainly on the functions of informational, legal and operational support, particularly: the analysis and provision of information to investors about the available projects, organization of tenders for the financing of projects and reporting about their results, the search of potential customers, providing them with information about the terms of lending; development of conditions for the participation of borrowers in tenders, control of the financial obligations of the parties, etc. 


\begin{tabular}{|c|c|c|c|c|}
\hline $\begin{array}{l}\text { - banks; } \\
\text { - physical persons; } \\
\text { - legal persons; } \\
\text { - state; } \\
\text {-non-residents. } \\
\text { Sum of investments: } \\
\quad \leq 200000 \text { UAN. }\end{array}$ & $\begin{array}{l}\text { Correspondent bank } 1 \\
\text { - deposition of investor } \\
\text { resources; } \\
\text { - provision of convenient } \\
\text { instruments of money transfer; } \\
\text { - systematization of investment } \\
\text { capital by maturity, currency; } \\
\text {-provision of customers with full } \\
\text { information about P2P-bank. }\end{array}$ & $\begin{array}{l}\text { - assuming responsibility for the } \\
\text { commitments of borrowers; } \\
\text { - transferring liquidity risks to investors; } \\
\text { - minimizing currency risks; } \\
\text { - minimizing the cost of credit; } \\
\text { - financing of the highest quality projects } \\
\text { and social projects; } \\
\text { - promotion of venture financing. }\end{array}$ & $\begin{array}{l}\quad \text { Correspondent bank } 2 \\
\text { - systematization of borrowers } \\
\text { and projects; } \\
\text { - authorization of borrowers; } \\
\text { - initial assessment of projects; } \\
\text { - accumulation of return cash } \\
\text { flows; } \\
\text { - calculation of borrower risks. }\end{array}$ & $\begin{array}{l}\quad \text { Borrowers: } \\
\text { - physical persons; } \\
\text { - small and medium } \\
\text { business; } \\
\text { - state; } \\
\text { - non-residents. } \\
\\
\text { Sum of investments: } \\
\text { Unlimited. }\end{array}$ \\
\hline $\begin{array}{l}\text { Investor risks } \\
\text { - lack of confidence in the } \\
\text { reliability of the borrower; } \\
\text { - doubts about the integrity } \\
\text { of P2P Bank; } \\
\text { - currency risk; } \\
\text { - operational risk; } \\
\text { - liquidity risk; } \\
\text {-interest-rate risk. }\end{array}$ & \begin{tabular}{|l} 
\\
- provision of information to \\
investors about the avalable \\
projects; \\
- analysis and characters of the \\
available projects; \\
- organization of tenders on \\
projects financing; \\
- information about the results of \\
tenders; \\
- search of customers.
\end{tabular} & & $\begin{array}{l}\downarrow \\
\text { - providing information on the } \\
\text { conditions of available credit; } \\
\text { - developing conditions for the } \\
\text { lenders' participation in the } \\
\text { tenders of projects' financing; } \\
\text { - control over the implementation of } \\
\text { financial obligations of the parties } \\
\text { in case of successful trading. }\end{array}$ & $\begin{array}{l}\text { Borrower risks: } \\
\text { - lack of confidence in } \\
\text { timely collection of the } \\
\text { required amount of } \\
\text { funds; } \\
\text { - risk of competition from } \\
\text { other borrowers; } \\
\text { - liquidity risk; } \\
\text {-interest-rate risk. } \\
\text { Borrower benefits: } \\
\text { - favorable interest rate: }\end{array}$ \\
\hline $\begin{array}{l}\text { Investor benefits: } \\
\text { - choice of favorable rates; } \\
\text { - choice of project; } \\
\text { - choice of borrower; } \\
\text { - independence in making } \\
\text { investment decisions; } \\
\text { - high level of transparency } \\
\text { of credit agreements; } \\
\text { - choice of currency. }\end{array}$ & $\begin{array}{l}\text { State } \\
\text { - restoring lending to the } \\
\text { economy; } \\
\text { - mobilization of resources of the } \\
\text { population outside the banking } \\
\text { system; } \\
\text { - possibility of financing } \\
\text { infrastructure projects; } \\
\text { - improving the stability of the } \\
\text { banking system. }\end{array}$ & $\begin{array}{l}\text { - responsibility for fair and transparent } \\
\text { doing of business; } \\
\text { - intensification of lending to the real } \\
\text { economy and economic development in } \\
\text { general; } \\
\text { - reduction of bank risks; } \\
\text { - opening of opportunities for financing } \\
\text { infrastructure projects; } \\
\text { - financing of projects with high added } \\
\text { value; } \\
\text { - development of the financial system. }\end{array}$ & \begin{tabular}{|l}
\multicolumn{1}{c}{ NBU } \\
$\rightarrow \begin{array}{l}\text { - development of the necessary } \\
\text { regulatory framework for the } \\
\text { development of participatory } \\
\text { lending; }\end{array}$ \\
- reducing the need of banks in \\
refinancing; \\
- control over transboundary \\
movement of capital; \\
- diversification of risks.
\end{tabular} & $\begin{array}{l}\text { - Independence from } \\
\text { bank; } \\
\text { - lack of currency risk } \\
\text { and interest-raterisk; } \\
\text { - high level of } \\
\text { transparency credit } \\
\text { agreements; } \\
\text { - possibility of payment } \\
\text { with goods. }\end{array}$ \\
\hline
\end{tabular}

Fig. 2. The mechanism of functioning of the system of participatory lending with participation of banks

Participating in the mechanism of multiparticipatory bank lending can be not only one bank, but also correspondent banks (in the absence of direct correspondent relations between the borrower/investor and the bank that carries out multiparticipatory bank lending). The functions of the correspondent bank, which will serve investors, are to ensure the deposition of their funds, to provide convenient instruments for the transfer of money, to systematize the attracted investment capital by maturity and currency, to provide complete information to customers about the bank that conducts multi-participatory bank lending. The functions of the correspondent bank, which serves borrowers, are to systematize the borrowers and their projects, to authorize borrowers, to make initial evaluation of projects, to accumulate reverse cash flows, to calculate risks for lenders.

Multi-participatory bank lending gives a number of benefits:

- for investors - a choice of favorable interestrate, a choice of project, a choice of borrower, independence in making investment decisions, high level of transparency of credit agreements, a choice of currency;
- for borrowers - favorable interestrates, independence from bank, minimization of the currency risk and interestrate risk, high level of transparency of credit agreements, the possibility of payment with goods.

- for banks - transferring liquidity risks to investors, minimizing currency risks, minimizing the costs of credit, financing of the highest quality projects and social projects, promotion of venture financing;

- for the state - restoring lending to the economy, mobilization of resources of the population outside the banking system, possibility of financing infrastructure projects, improving the stability of the banking system;

- for the National Bank of Ukraine - reducing the need of banks in refinancing, control over transboundary movement of capital, diversification of risks.

Given the fact that the share of problem loans, which are provided by the platforms of multi-participatory lending, in different countries, on average, do not exceed $2 \%$, it seems appropriate to introduce this mechanism in the Ukrainian banks in the context of improving the quality of their loan portfolios. 


\section{Conclusions and prospects for further research}

The study of the development of P2P lending in the world and Ukraine and its comparison with bank lending in the post-crisis period made it possible to identify a number of key problems in Ukraine that restrain its development, namely:

- reduction of public confidence to the banks (2008-2015 - by almost 3 times, namely from 59.2 to $21.2 \%$ ), which caused a massive withdrawal of deposits from banks;

- increase in the share of problem loans (for the period 2008-2014 - by almost 10 times, namely from 1.3 to $13.5 \%$ ), leading to an increase of losses in the banking system by 9 times;

- increase in the cost of credit (for the period 2008-2015, the weighted average interest-rate on credits in the national currency increased from 13 to $20.7 \%$ ), resulting in lower credit activity of domestic companies and, consequently, the decline in the volumes of production;

- for the Ukrainian credit market, it is too early to predict big growth rates in the development of P2P loans, given the lack of mass information provision regarding the credit histories of borrowers, insufficient transparency of financial reporting of business entities, low level of financial literacy of private creditors and their propensity for conservative investment models.
In the context of intensification of bank lending, it is offered to introduce its new form - multiparticipatory bank lending ("multi" - because many investors are expected to participate in lending to a single borrower (project), "participatory" - because of the direct participation of the investor in choosing the borrower and credit conditions). This form of financial intermediation is a combination of characteristics of the traditional bank lending, bank intermediation and a new form of financial relations that have been formed outside the formal financial market - P2P lending. In essence, remaining a part of $\mathrm{P} 2 \mathrm{P}$ lending, this service goes under the partial control of the bank because the bank is the organizer and provider of such services. The production of this service by the Ukrainian banks is expedient, because considering the low levels of overall confidence of economic agents to the financial sector, banks still remain the most popular and reliable financial intermediaries compared to insurance companies, mutual and corporate investment funds, credit unions, pawnshops, etc.

In fact, it would turn depositors into investors, because they would take on a number of risks, including: credit, liquidity, interestrate and currency risks. However, the shifting of risks from the bank to the depositor should be compensated by higher profitability of such operations compared to the depositary ones by minimizing bank margins.

\section{References}

1. Artamonov, V. (2012). Koly v Ukraini zjavitsja kraudfandynh? [When will crowdfunding appear in Ukraine] [Electronic resource]. Website of the journal "Forbes Ukraine". Available at: http://forbes.ua/opinions/1334049-kogda-v-ukrainepoyavitsya-kraudfanding [in Russian].

2. Bolshoy biznes vytesniaet chastnikov iz setei pirinhovykh zaimov [Big business drives out private business owners from peer-to-peer loans networks] [Electronic resource]. Rosbizneskonsalting [Russian business consulting] (November 18, 2016). Available at: http://top.rbc.ru/economics/18/11/2013/889256.shtml [in Russian].

3. Vasylchuk, I. (2013). Kraudfandynh ta kraudinvestinh jak finansovi innovatsii [Crowdfunding and crowdinvesting as financial innovations], Rynok tsinnykh paperiv Ukrainy [Stock market of Ukraine], 11-12, pp. 59-67 [in Ukrainian].

4. Vasylchuk, I.P. (2013). Kraudfandynh jak fenomen postindustrialnoii ekonomiky [Crowdfunding as a phenomenon of post-industrial economy], Efektyvna ekonomika [Effective economy], 11. Available at: http://www.economy.nayka.com.ua/?op=1\&z=2500 [in Ukrainian].

5. Vlasov, A.V. (2012). Elektronnye denhi i evolutsionaiia teoriia proiskhozhdeniia deneh [Electronic money and evolutionary theory of origin of money], Nauka i obrazovaniie: khoziaistvo i ekonomika; predprinimatelstvo; pravo i upravleniie [Science and education: household and economy; entrepreneurship; right and governance], 12, pp. 13-23 [in Russian].

6. Gates, B. (2007). Biznes so skorostju mysli [Business with speed of a thought]. (2d ed. rev.). Moscow: Eksmo, 480 p. [in Russian].

7. Dluhopolskyi, O.V. (2011). Suspilnyi sektor ekonomiky i publichni finansy v epokhu hlobalnykh transformatsiy [Public sector of economy and public finance in the epoch of global transformations]. Monogr. Ternopil: Ekon. Dumka TNEU, 632 p. [in Ukrainian].

8. Dluhopolskyi, O.V. (2012). Reformuvannia suspilnoho sektoru ekonomiky ta novi pidkhody do upravlinnia publichnymy finansamy [Reforming of public sector of economy and new approaches to management of public finance] [Text]: [monograph]. K.: Derzh. navch.-nauk. Ustanova “Akad. fin. upr.”, 278 p. [in Ukrainian].

9. Dolhin, A.B. (2013). Kak nam stat' dohovoroprihodnymi, ili Prakticheskoje rukovodstvo po kollektivnym dejstvijam [How can we become contract suitable, or Practical guidelines on collective actions]. M.: OGI, 192 p. [in Russian].

10. Petrushenko, Yu.M., Dudkin, O.V. (2014). Kraudfandynh jak innovatsijniy instrument finansuvannia proektiv sotsialnoekonomichnoho rozvytku [Crowdfunding as an innovative instrument of financing the projects of social and economic 
development], Marketynh i menedzhment innovatsiy [Marketing and management of innovations], 1, pp. 172-182 [in Ukrainian].

11. Petrushenko, Yu.M. (2014). Rozvytok metodiv kollektyvnoho finansuvannia jak factor sotsialno-ekonomichnoho rozvytku terytorialnykh hromad [Development of methods of collective financing as a factor of social and economic development of territorial communities], Svit finansiv [World of finance], 1, pp. 106-113 [in Ukrainian].

12. Stvorennia Spilnokoshtu na Velykiy Idei [Electronic resource]. Available at: http://biggggidea.com/project/18.

13. Official web-site of World Bank [Electronic resource]. Available at: http://databank.worldbank.org/data/home.aspx.

14. Official web-site "British Peer-to-Peer Financial Association" [Electronic resource]. Available at: p2pfa.info.

15. Official web-site "SimZirok" [Electronic resource]. Available at: http://www.simzirok.com.

16. Official web-site "Center of economy and business research" (CEBR) [Electronic resource]. Available at: http://www.cebr.com/.

17. Agrawal, A., Catalini, C., Goldfard, A. (2011). The geography of crowdfunding. NBER Working Paper №16820 [Electronic resource]. Available at: http://www.nber.org/papers/w16820.pdf.

18. Agrawal, A., Catalini, C., Goldfard, A. (2013). Some simple economics of crowdfunding. NBER Working Paper № 19133 [Electronic resource]. Available at: http://www.nber.org/papers/w19133.pdf.

19. Ahlers, G.K.C., Cumming, D., Gunther, C., Schweizer, D. (2012). Signaling in equity crowdfunding. Working Paper [Electronic resource]. Available at: http://papers.ssrn.com/sol3/Delivery.cfm/SSRN_ID2245529_code744422.pdf

20. The Economist. (2013). Banking without banks. Finance and economics. [Ēlectronic resource]. Available at: http://www.economist.com/news/financeand-economics/21597932-offering-both-borrowers-and-lenders-better-dealwebsitesput-two.

21. Belleflamme, P., Lambert, T., Schwienbacher, A. (2014). Crowdfunding: Tapping the right crowd, Journal of Business Venturing, forthcoming [Electronic resource]. Available at: http://papers.ssrn.com/sol3/Delivery.cfm/SSRN_ID2292363 code301672.pdf.

22. Burkett, E. (2011). Crowdfunding exemption? Online investment crowdfunding and US securities regulation, Transactions: Tennessee Journal of Business Law, 13, pp. 63-106.

23. Crowdfunding Industry Report: Market Trends, Composition And Crowdfunding Platforms [Electronic resource]. Available at: http://www.crowdfunding.nl/wp-content/uploads/2012/05/92834651-Massolution-abridged-CrowdFunding-Industry-Report1.pdf

24. Chen, N., Ghosh, A., Lambert, N.S. (2011). Auctions for Social Lending: A Theoretical Analysis. Research Paper №2078. Stanford: Graduate School of Business [Electronic resource]. Available at: http://gsbapps.stanford.edu/researchpapers/library/RP2078.pdf.

25. Goff Sh. Peer-to-peer lending Model takes off worldwide. Financial Times. Available at: http://www.ft.com/cms/s/0/bb517d8a-a5ad-11e1-a3b4-00144feabdc0.html\#axzz4ET41Ukgn.

26. Hallen, B.L., Eisenhardt, K.M. (2012). Catalyzing strategies and efficient tie formation: how entrepreneurial firms obtain investment ties, The Academy of Management Journal, 55, pp. 35-70.

27. Hemer, J. (2011). A snapshot on crowdfunding. The Open Access Publication Server of the ZBW, pp. 1-39.

28. Jenkins, H., Clinton, K., Purushotma, R., Robinson, A., Weigel, M. Confronting the Challenges of Participatory Culture: Media Education for the 21-st Century [Electronic resource]. Available at: http://mitpress.mit.edu/sites/ default/files/titles/free_download/9780262513623_Confronting_the_Challenges.pdf.

29. Jumpstart Our Business Startups Act: An act to increase American job creation and economic growth by improving access to the public capital markets for emerging growth companies (signed into law on April 5, 2012) [Electronic resource]. Available at: http://www.gpo.gov/fdsys/pkg/BILLS-112hr3606enr/pdf/BILLS- 112hr3606enr.pdf.

30. Kuppuswamy, V., Bayus, B. (2013). Crowdfunding creative ideas: the dynamics of project backers in Kickstarter. Working Paper.

31. Lerner, J. (1995). Venture Capitalists and the Oversight of Private Firms, Journal of Finance, 50, pp. 310-318.

32. Light, J. Is "Peer-to-Peer" Lending worth the risk? The Wall Street Journal. Available at: http://www.wsj.com/articles/SB10001424052702304587704577333801201736034.

33. Lin, M., Viswanathan, S. (2013). Home Bias in Online Investments: An Empirical Study of an Online Crowd Funding Market. [Electronic resource]. Available at: http://funginstitute.berkeley.edu/wpcontent/uploads/2013/11/Home_Bias_Online_Investments.pdf

34. Ley, A., Weaven, S. (2011) Exploring Agency Dynamics of Crowdfunding in Start-up Capital Financing, Academy of Entrepreneurship Journal, Vol. 17, Number 1, pp. 85-110.

35. Mollick, E. (2014). The Dynamics of Crowdfunding: An Exploratory Study, Journal of Business Venturing, 29 (1), pp. 1-16.

36. Morduch, J. (1999). The microfinance promise, Journal of Economic Literature, 37, pp. 1569-1614.

37. Poetz, M., Schreier, M. (2012). The value of crowdsourcing: can users really compete with professionals in generating new product ideas? Journal of Product Innovation Management, 29, pp. 245-256.

38. Schwienbacher, A., Larralde, B. (2010). Crowdfunding of small entrepreneurial ventures, SSRN Electronic Journal. [Electronic resource]. Available at: http://papers.ssrn.com/sol3/Delivery.cfm/SSRN_ID1699183_code301672.pdf.

39. Web-site "United Prosperity". [Electronic resource]. Available at: http://www.unitedprosperity.org/us/about_us. 